\title{
A nemzetközi diverzifikáció, az innováció és a teljesítmény kapcsolata az európai élelmiszer-kiskereskedelemben
}

Kutatásunk során azt vizsgáltuk, hogy miként hat a nemzetközi diverzifikáció a nagy európai élelmiszer-kiskereskedelmi vállalatok piaci teljesítményére és innovációs tevékenységére. A világ 250 legnagyobb kiskereskedőjét tartalmazó toplista alapján az európai kiskereskedelmi vállalatok rendelkeznek a leginkább kiterjedt globális jelenléttel, ami jelentősen növeli a kiskereskedelmi tevékenységük nemzetközi diverzifikáltságát. A szakirodalom feltételezése alapján a nemzetközi diverzifikáció számos előnyt nyújt a vállalatok számára, például új erőforrásokhoz, innovációs lehetőségekhez való hozzáférést vagy a piaci kockázat csökkentését. Másodlagos források alapján paneladatbázist építettünk a 2008-2013 közötti időszakra. Elemzésünk során kimutattuk, hogy a nemzetközi diverzifikáció és a kiskereskedelmi vállalatok folyamatinnovációs tevékenysége között a kapcsolat nem lineáris. A nemzetközi diverzifikáció továbbá fordított $U$ alakú összefüggést mutat a vállalatok nyereségességével. Végül, a marketing-, termék- és folyamatinnováció pozitív, késleltetett hatást gyakorol az élelmiszer-kiskereskedelmi vállalatok nyereségességére.* Journal of Economic Literature (JEL) kód: M31, L81.

A nyolcvanas évek végétől erőteljes nemzetközi terjeszkedést lehetett megfigyelni a kiskereskedelmi szektorban (Treadgold [1988/2009]). Az európai kiskereskedők körében különösen jellemző volt, hogy kiskereskedelmi hálózatukat kiterjesztették más országokra. A német, illetve francia alapítású kereskedelmi vállalatok árbevételük közel 40 százalékát külföldi piacokon termelik meg (Deloitte [2016]).

A menedzsmentelméleti megközelítések szerint a nemzetközi diverzifikáció többféle előnyt nyújt a vállalatok számára: például az új erőforrásokhoz való hozzáférést, az innovációs képességek fejlesztését, továbbá a piaci kockázat csökkentését (Hitt és szerzőtársai [2006]). A nemzetközi diverzifikáció teljesítménykövetkezményeit a

\footnotetext{
* Berezvai Zombor kutatását az Emberi Erőforrások Minisztériuma ÚNKP-16-3-II kódszámú Új Nemzeti Kiválóság Programja támogatta.
}

Agárdi Irma, Budapesti Corvinus Egyetem. Berezvai Zombor, Budapesti Corvinus Egyetem. Alt Mónika-Anetta, Babes-Bolyai Egyetem. 
menedzsment- és a kiskereskedelmi szakirodalom (Gielens-Dekimpe [2001], Qian és szerzötársai [2010], Chan és szerzőtársai [2011], Sohl [2012], Oh és szerzötársai [2015]) behatóan vizsgálta. A vezető európai kiskereskedőkre azonban nem csupán a földrajzi terjeszkedés, hanem az intenzív innovációs tevékenység $(\mathrm{K}+\mathrm{F}$-laborok létrehozása, új technológiák felkarolása) is jellemző (Deloitte [2015]). Ennek ellenére nagyon kevés kutatás (Hitt és szerzötársai [1997], Michalache [2015]) készült arról, hogy a nemzetközi diverzifikáció hogyan befolyásolta a kiskereskedelmi vállalatok innovációs tevékenységét.

A cikk e kutatási területen arra a kérdésre keresi a választ, hogy miként befolyásolja a nemzetközi diverzifikáció a kiskereskedelmi innovációt, illetve milyen teljesítménykövetkezményei vannak a nemzetközi diverzifikációnak és a kiskereskedelmi innovációnak a vezető európai élelmiszer-kiskereskedők esetében. A kutatás két fontos területen járul hozzá a kiskereskedelmi szakirodalomhoz. Egyrészt, elemezzük a nemzetközi diverzifikáció innovációra gyakorolt hatását. Másrészt, kvantitatív módszerekkel vizsgáljuk a kiskereskedelmi innováció teljesítménykövetkezményeit. Az elemzéshez különböző másodlagos forrásokból összeállított paneladatbázist használunk.

A cikk a következőképpen épül fel. Először a nemzetközi diverzifikáció és a kiskereskedelmi innováció szakirodalmát tekintjük át. Majd a kutatási elgondolás és a hipotézisek kifejtésére kerül sor. A módszertan ismertetése után részletesen bemutatjuk a kutatási eredményeket. Végül összegezzük a legfontosabb megállapításainkat, illetve azok tudományos és üzleti alkalmazási lehetőségeit.

\section{Szakirodalmi áttekintés}

\section{Nemzetközi diverzifikáció}

Hitt és szerzőtársai [2006] szerint a nemzetközi diverzifikáció olyan stratégia, amelynek során a vállalat termékeinek és szolgáltatásainak értékesítését más földrajzi helyekre (országokra, régiókra) terjeszti ki. Wiersema-Bowen [2011] ennél tovább megy, és a vállalati értéklánc (beszerzés, termelés, értékesítés) külföldi piacokra való kiterjesztését tekinti földrajzi diverzifikációnak. A nemzetközi diverzifikáció növelheti a vállalat nemzetközi versenyképességét (Rugman és szerzötársai [2012]) a méret- és választékgazdaságosságnak, a külföldi piacokon szerzett tudásnak, illetve a kockázatcsökkentésnek köszönhetően. Másrészről viszont a belföldi piacon túlnyúló tevékenységek koordinációja és ellenőrzése miatt költségnövekedéssel is számolhatnak a vállalatok.

Az európai kiskereskedők nemzetközi terjeszkedését számos tényező motiválta. A kiskereskedelmi vállalatok a hazai piacokon gyakran ütköztek jogi korlátokba új, főként nagy alapterületű üzletek építése során. Másrészt, a belső kereslet stagnálása miatt kerestek olyan piacokat, amelyek nagyobb növekedést mutattak. A kiskereskedők számára az is fontos, hogy a beszerzésben és az ellátási láncban méretgazdaságosságot érjenek el. Végül pedig a fejlődő piacokra való belépés sokszor kevesebb 
erőfeszítésbe kerül, mivel a vállalat a már bejáratott menedzsment- és kiskereskedelmi módszerekkel jelentős versenyelőnyre tehet szert (Deloitte [2009]).

Burt és szerzötársai [2008] áttekintette a kiskereskedelem nemzetközi diverzifikációjának elméleteit. Meglátásuk szerint két tipikus megközelítés fordul elő a legtöbb modellben. Az egyik a hazai piactól való földrajzi, kulturális távolság jelentőségére helyezi a hangsúlyt, a másik pedig a külföldi piachoz való alkalmazkodás mértékére. Valójában ez a két megközelítés egymással kölcsönhatásban fejti ki hatását. A kiskereskedelmi vállalatok először a földrajzilag és kulturálisan közel fekvő piacokra lépnek be, ami nem igényli az üzleti modell jelentős megváltoztatását. Idővel mélyebben megismerik az új piacok müködését, majd a megszerzett tapasztalatokkal felvértezve terjeszkednek földrajzilag és kulturálisan távolabbi piacokra (Oh és szerzőtársai [2015]). A földrajzi terjeszkedésnek ezt a szabályszerüségét vette alapul Qian és szerzőtársai [2010], és különbséget tett régión belüli (azonos régióban elhelyezkedő országok), illetve régiók közötti (egymástól nagyobb földrajzi és kulturális távolságra fekvő régiók) terjeszkedés között. Régiók közötti terjeszkedés során nagyon eltérö versenyhelyzettel, erőforrásokkal, vásárlói magatartással és beszállítói hálózattal találhatja szemben magát a kiskereskedő. Ennek következtében a vállalatnak egyre nagyobb mértékben kell alkalmazkodnia a helyi piaci feltételekhez, azaz nagy az adaptációs igény.

$\mathrm{Az}$ adaptáció mértéke azt mutatja meg, hogy a menedzsment milyen mértékben reagál a külföldi piac müködési különbségeire. A kiskereskedőnek döntést kell hoznia, milyen mértékben standardizálja a beszerzési, marketing- és operatív tevékenységeit. Ha a méretgazdaságosság kap elsőbbséget, akkor a vállalat nagyobb standardizációra törekszik az üzlettípusokban, áruválasztékban, kiskereskedelmi márkákban, amit segít az erős központi kontroll és az értéklánc vertikális integrációja. Ebben az esetben a kiskereskedő inkább átfogó, általános stratégiát igyekszik megvalósítani. Ellenkező esetben a kiskereskedő multiregionális megközelítést alkalmaz, amelynek során az adott külföldi piacra szabja a kiskereskedelmi tevékenységét (Salmon-Tordjman [1989/2009]).

\section{Kiskereskedelmi innováció}

Az innováció fogalma szorosan kapcsolódik Schumpeter [1911/1980] elméletéhez, amely azt feltételezi, hogy a gazdasági fejlödést olyan új, időnként felbukkanó megoldások befolyásolják, amelyek az előzőkhöz képest gazdaságilag életképesebbnek bizonyulnak. Az innováció fogalma komplex, a körülményektől függő jelenség (Neely és szerzötársai [2001]). Hristov-Reynolds [2007] szerint a kiskereskedelmi innováció kutatása még gyermekcipőben jár. Az angol kiskereskedelmi szektorban végzett szakértői interjúk alapján a szerzőpáros bemutatta, hogy a kiskereskedelmi innováció - eltérően más iparági innovációktól - legtöbbször vertikális együttmüködésben valósul meg. A kiskereskedelmi vállalatok ugyanis az értékesítési csatornában a gyártó és a fogyasztó közötti közvetítőként vannak jelen, azaz az innovációs megoldásaik gyakran a beszállítókkal, a vevőkkel, illetve más partnerekkel való együttmüködésben jönnek létre (Brondoni és szerzötársai [2013]). Ráadásul a 
kiskereskedők innovációs ciklusaiban gyakran fordítva alakulnak a ráfordítások: az első ciklusban relatíve alacsonyak a beruházási költségek, viszont az innováció bevezetésekor magasak (Hristov-Reynolds [2015]).

Néhány tanulmány (Medina-Rufín [2009], Reinartz és szerzőtársai [2011], Brondoni és szerzőtársai [2013], Hristov-Reynolds [2015]) foglalkozott már a kiskereskedelmi innováció jellemzőinek feltárásával, azonban mindegyik adós maradt a kiskereskedelmi innováció definiálásával. A kiskereskedelem jellegzetességeit figyelembe véve kiskereskedelmi innovációnak tekintünk minden olyan, a kiskereskedő értékláncához kapcsolódó változtatást, amely új vagy jelentősen javított megoldáshoz vezet, és üzleti hasznosításra kerül.

A kiskereskedelmi innováció számtalan formát ölthet, így például idetartozik az új üzlettípusok vagy kiskereskedelmi márkák bevezetése, a választék jelentős átalakítása, a fogyasztói élmény növelése, informatikai fejlesztés, új média, fizetési és rendelési mód alkalmazása (Reinartz és szerzőtársai [2011]). A kiskereskedelmi innováció főbb típusainak megragadására több kutató tett kísérletet. Az egyik lehetséges osztályozás a technológiai és nem technológiai innovációk közötti különbségtétel. Niemeier és szerzötársai [2013] a kiskereskedőket technológiai cégeknek nevezik, mivel a nagy méretü cégeknél a technológiai fejlesztés központi szerepet játszik. Érdemes azonban megjegyezni, hogy a kiskereskedők többnyire az új technológiai megoldásokat más iparágakból adaptálják (Pantano [2014]). A kiskereskedelmi technológiai innovációt egyrészt az infokommunikációs ipar fejlesztései, másrészt a fogyasztók gyors technológiaelfogadása hajtja elöre (Pantano-Viassone [2014]).

Hristov-Reynolds [2015] ajánlati, támogató és szervezeti innovációkat különített el a kiskereskedelemben. Az ajánlathoz kötődő innovációkkal a végső fogyasztókat kívánják elérni, a támogató innovációk az ajánlatok létrehozásához füződő technológiákat és rendszereket foglalják magukban. Végül, a szervezeti innovációk olyan stratégiai és operatív megoldások bevezetését jelentik, amelyek segítik a vállalaton belüli kommunikációt, vagy folyamatokat automatizálnak a hatékonyság növelése érdekében.

Az egyik leggyakrabban alkalmazott megközelítés (például Drejer [2004], Cascio [2011], Dellestrand [2011], Inauen-Schenker-Wicki [2012], Hassan és szerzötársai [2013]) az OECD-Eurostat [2005] által kialakított innovációs tipológia (Oslo kézikönyv), amely termék-, marketing-, szervezeti és folyamatinnovációk között tesz különbséget.

Termékinnovációnak tekinthető az új vagy jelentősen javított termék és/vagy szolgáltatás kifejlesztése és bevezetése (Neely és szerzőtársai [2001]). A termékinnováció a termék vagy szolgáltatás működőképességét változtatja meg úgy, hogy az magasabb felhasználói értéket jelent a vevő számára (OECD-Eurostat [2005]). A kiskereskedők esetében a termékinnováció leginkább új kiskereskedelmi márkák fejlesztését és bevezetését jelenti. Fornari és szerzötársai [2009] több altípust azonosított a termék újdonságértéke alapján: teljesen új termék, új termékvonal, termékvonal kibővítése, jelenlegi termék fejlesztése, újrapozicionálás és költségcsökkentés.

A marketinginnovációt elsőként Levitt [1960] definiálta olyan új módszerként, amely a menedzsment vagy piackutatás által azonosított fogyasztói igényeket hivatott 
kielégíteni. Ennél jóval specifikusabb meghatározást alkalmaz az OECD-Eurostat [2005], amely magában foglalja a termékdizájnt, illetve a csomagolási, árukihelyezési, árképzési, promóciós és pozicionálási stratégia megváltoztatását is, amennyiben az jelentős újdonságértéket hordoz, és a vállalat értékesítését hivatott növelni.

A vásárló személyére összpontosító marketing (shopper marketing) számtalan eszközt tartalmaz, amely marketinginnovációs tevékenység célja lehet, és az összes, a fogyasztó útját befolyásoló marketingtevékenységet magában foglalja (Shankar és szerzőtársai [2011]). Ilyen innováció lehet egy új árképzési modell (például dinamikus árazás) vagy promóciós eszközök (például digitális kuponok) bevezetése (Grewal és szerzőtársai [2011]). A marketinginnováció másik népszerü területe az új üzletdizájn kialakítása (Shankar és szerzőtársai [2011]). Az új üzlettípusok a marketinginnováció komplexebb formáját jelentik (Reynolds és szerzötársai [2007]), amely az összes kiskereskedelmi eszközt (áruválaszték, árképzés, kommunikáció, szolgáltatások, telephely és eladótér kialakítása) magában foglalja. Chen [2006] kétféle marketinginnovációt különböztet meg. Az első típusba azok az innovációk tartoznak, amelyek új információtechnológiai beruházások révén képesek növelni a kiskereskedők marketingtevékenységének hatásfokát. A másik típusba tartozó innovációk a fogyasztók tranzakciós költségeinek csökkentésére irányulnak új kereskedelmi eljárások, üzlettípusok, illetve csatornák fejlesztésével.

A kutatók véleménye megoszlik a szervezeti innovációval kapcsolatban. Cascio [2011] például szervezeti innovációnak tartja a marketing- és folyamatinnovációt is. Az OECD-Eurostat [2005] viszont szükebben kezeli ezt a típust: a külső és a munkahelyi kapcsolatok új módjaként definiálja a szervezeti innovációt. Ilyen szervezeti megoldások lehetnek a tudásmenedzsment új formái, a munkafolyamatok, külső kapcsolatok szervezésének új megoldásai, amelyeket a vállalat korábban még nem alkalmazott, és a vezetés stratégiai döntése alapján jöttek létre.

A folyamatinnovációk azokat a módszereket fogják át, amelyek révén termékek vagy szolgáltatások új vagy jelentősen javított módon jutnak el a fogyasztókhoz. A folyamatinnovációk középpontjában a belső szervezet hatásosságának és hatékonyságának növelése áll (Damanpour és szerzötársai [2009]). A kiskereskedők folyamatinnovációi részben technológiai jellegüek - például rádiófrekvenciás azonosítás (radio-frequency identification, RFID), 3D nyomtatás, hangalapú raktári vezérlés -, részben pedig új disztribúciós folyamatok - például új csatorna (mobil- vagy közösségi kereskedelem) - bevezetését jelentik.

\section{Kutatási megközelítés}

Kutatásunk célja, hogy megvizsgáljuk a nemzetközi diverzifikáció kiskereskedelmi innovációra gyakorolt hatását, illetve számszerüsítsük azt, hogy milyen hatással van a nemzetközi diverzifikáció és az innováció a vállalatok pénzügyi teljesítményére a vezető európai élelmiszer-kiskereskedelmi vállalatok esetében. Az 1. ábra áttekintést ad a nemzetközi diverzifikáció, a kiskereskedelmi innováció és a pénzügyi teljesítmény között feltételezett kapcsolatokról. 
1. ábra

A nemzetközi diverzifikáció, a kiskereskedelmi innováció és a pénzügyi teljesítmény között feltételezett összefüggések

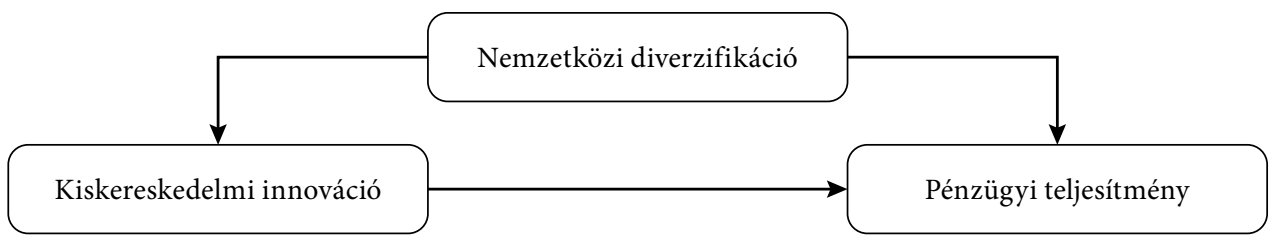

A nemzetközi diverzifikáció hatása a kiskereskedelmi innovációra

Jóllehet a vezető kiskereskedelmi vállalatok régóta jelen vannak a nemzetközi színtéren, a kiskereskedelmi szakirodalom mégsem foglalkozott a nemzetközi diverzifikáció és az innováció kapcsolatával. Ennek hiányában a menedzsment-szakirodalomban található kutatásokat tekintettük át, ahol néhány kutató vizsgálta a nemzetközi diverzifikáció és az innovációs tevékenység összefüggését (Castellani-Zanfei [2007], Frenz-Ietto-Gillies [2007], Siedschlag-Zhang [2015], Xie-Li [2015]). A kutatók jelentős része pozitív kapcsolatot feltételezett az innováció és a nemzetközi diverzifikáció között, azaz a külföldi piacokon való eröteljesebb jelenlét intenzívebb innovációs tevékenységet vont maga után. A pozitív kapcsolat alátámasztására Filippetti és szerzőtársai [2013] számos érvet sorakoztatott fel. Egyrészt, a nemzetközi diverzifikáció nagyobb piaci jelenlétet tesz lehetővé, amely segít a vállalatoknak az üzleti kockázatok csökkentésében és az innováció megtérülésében. Következésképpen, a nemzetközi diverzifikáció ösztönzi az innovációt elősegítő beruházásokat (Hitt és szerzőtársai [1997]). Zahra és szerzőtársai [2000] bebizonyította, hogy a nemzetközi diverzifikáció szélesíti és mélyíti az innovációs tevékenységhez szükséges szervezeti, technológiai tanulást. Másrészt, a nemzetközi diverzifikáció során a vállalatoknak egyre változatosabb piaci környezetben és versenyhelyzetben kell müködniük, ami gazdagítja a szervezeti tudást is. A szervezeti tanulást különösen az támogatja, ha a külföldi leányvállalatok megosztják egymással a különböző piacaikon szerzett tapasztalataikat (Filippetti és szerzőtársai [2013]). Nem csupán a belső szervezeti folyamatok révén, hanem a külső partnerkapcsolatok is vezethetnek innovatív elgondolások megvalósításához (Dellestrand [2011]).

Hitt és szerzötársai [1994] arra is rámutatott, hogy a nemzetközi diverzifikáció és az innováció között nem feltétlenül lineáris a kapcsolat. A vállalat földrajzi terjeszkedése csak egy bizonyos pontig befolyásolja pozitívan az innovációs tevékenységet, mivel egy bizonyos méret fölött a vállalat koordinálási költségei jelentősen megnőnek, és kevesebb erőforrás jut az innovációs tevékenységre. Ezt a feltételezést támasztotta alá Michalache [2015] kutatása is, amely szerint a nemzetközi diverzifikáció és az innováció között negatív kvadratikus kapcsolat van, azaz először a nemzetközi diverzifikáció pozitívan befolyásolja az innovációt, majd egy meghatározott pont után megfordul a kapcsolat, és negatív hatás jelentkezik. A fenti összefüggések alapján a következö hipotézist fogalmazzuk meg: 
$H_{1}$ : a nemzetközi diverzifikáció negatív kvadratikus hatást gyakorol a kiskereskedelmi innovációra.

A hatás erőssége azonban innovációtípusonként változhat. A termék- és marketinginnovációra erőteljesebben hathat a földrajzi terjeszkedés, míg a szervezeti és folyamatinnováció kevésbé kultúra- és piacfüggő (Bauer-Carman [1996]).

\section{A nemzetközi diverzifikáció hatása a pénzügyi teljesítményre}

Számos kutató vizsgálta a nemzetközi diverzifikáció teljesítményt befolyásoló szerepét. Hitt és szerzőtársai [2006] e szempontból tekintette át a témában megjelent korábbi kutatásokat. Sohl [2012] úgy vélte, hogy a nemzetközi diverzifikációnak nem lineáris hatása van a vállalati teljesítményre. A régión belüli terjeszkedés pozitívan hat a vállalat jövedelmezőségére, a régiók közötti terjeszkedés viszont növeli a vállalati müködés komplexitását, és negatív kvadratikus kapcsolatot ír le a teljesítménnyel. Oh és szerzötársai [2015] ökonometriai módszerekkel igazolta, hogy a nemzetközi diverzifikáció $S$ alakú kapcsolatot ír le a pénzügyi teljesítménnyel. A távolabbi piacok nagyobb mértékü alkalmazkodást igényelnek, ami költségesebbé teszi a kiskereskedelmi hálózat működtetését, ezért kisebb profitot realizálnak a vállalatok. Számos európai kiskereskedő elöször régión belül, a hazai piactól kevésbé eltérő (például közép- és kelet-európai) országok felé terjeszkedett, csak később lépett be új régiókba (például ázsiai piacokra). A fentiek következtében fogalmazzuk meg a második hipotézist:

$\mathrm{H}_{2}$ : a nemzetközi diverzifikáció nem lineáris, $S$ alakú hatást gyakorol a kiskereskedelmi vállalatok pénzügyi teljesítményére.

\section{A kiskereskedelmi innováció hatása a pénzügyi teljesítményre}

A vállalatok innovációs tevékenységének fö célja, hogy növeljék a piacon versenyképességüket, és ezáltal jobb vállalati teljesítményt érjenek el. A sikeres innovációk magasabb termékminőséghez, szolgáltatás-színvonalhoz vezetnek (Hitt és szerzőtársai [1994], Neely és szerzőtársai [2001]), ami pozitívan hat a vállalati teljesítményre. Hassan és szerzőtársai [2013] mindegyik innovációtípus esetében a piaci és pénzügyi teljesítmény növekedését feltételezte. Siedschlag-Zhang [2015] hasonlóan vélekedett, azaz a termék-, marketing-, folyamat- és szervezeti innovációk, illetve a vállalati termelékenység kapcsolatát lineáris, pozitív összefüggéssel írta le. Kimutatta, hogy a szervezeti és folyamatinnováció járul leginkább hozzá a termelékenységhez. Cascio [2011] viszont a marketinginnováció és a szervezeti teljesítmény között nem lineáris összefüggést talált több iparágban is. Meglátása szerint a marketinginnováció az első szakaszban nagyobb mértékben járul hozzá a teljesítményhez, mert a cégek elöször alacsony kockázatú innovációkat valósítanak meg. Később a vállalat magasabb kockázatú innovációkkal jelenik meg a piacon, ami alacsonyabb megtérüléshez vezet. A kiskereskedelmi vállalatokra azonban ez nem feltétlenül jellemző, mivel párhuzamosan több, eltérö kockázatú innovációval is foglalkoznak. 
Az innovációk megtérülését illetően az a feltételezésünk, hogy késleltetett hatásuk van a vállalat jövedelmezőségére, mivel a piacnak időre van szüksége, hogy az innovatív megoldásokat felkarolja. A profitabilitásban így tehát később jelentkeznek a hatások (Geroski és szerzőtársai [1993], Hitt és szerzőtársai [1994]). A harmadik hipotézisünk a következő:

$H_{3}$ : a kiskereskedelmi innováció pozitív, késleltetett hatást gyakorol a kiskereskedelmi vállalatok pénzügyi teljesítményére.

\section{Kutatási módszertan és a változók operacionalizálása}

A nemzetközi diverzifikáció, a kiskereskedelmi innováció és a piaci teljesítmény kapcsolatára vonatkozó hipotéziseket vezető európai, élelmiszereket és napi fogyasztási cikkeket forgalmazó kiskereskedők körében vizsgáltuk. A kutatásban részt vevő kiskereskedőket a Deloitte által évente publikált Global Powers of Retailing top 250 listából válogattuk le. ${ }^{1}$ Összesen 50 európai székhelyű élelmiszer-kiskereskedelmi vállalatot azonosítottunk, ${ }^{2}$ amelyeknek nemzetközi diverzifikációs és innovációs tevékenységéről, illetve teljesítményéről gyüjtöttünk adatokat különböző forrásokból (Global Powers of Retailing riportok, éves jelentések, üzleti hírek).

A nemzetközi diverzifikáció időbeli változásai, illetve az innováció teljesítményre gyakorolt, késleltetett hatásai paneladatbázis létrehozását tették szükségessé. Az időszak kiválasztásánál figyelembe vettük, hogy a globális pénzügyi válság egyaránt hatással volt a vállalatok teljesítményére, innovációs tevékenységére és nemzetközi terjeszkedésére is. A válság hatására például több kiskereskedelmi vállalat a növekedési lehetőségeket a földrajzi terjeszkedésben látta (Pederzoli-Kuppelwieser [2015]). Kutatásunk során a 2008 és 2013 közötti időszakra gyüjtöttünk adatokat, tehát a válság alatti és utáni időszakaszra is. Az adatgyüjtés során több vállalat innovációs és/vagy nemzetközi diverzifikációra vonatkozó információi hiányoztak, így 37 vállalat hat évre vonatkozó adatai, összesen 222 adatpont állt rendelkezésünkre.

A modellben szereplö változókat a következőképpen számszerüsítettük. A nemzetközi diverzifikációt azon országok számával mértük, amelyekben a vállalat kiskereskedelmi tevékenységet végzett az adott évben. Oh és szerzőtársaival [2015] ellentétben nem bontottuk meg a földrajzi diverzifikációt intra- és interregionális részre, ugyanis ennek elkülönítése problematikus. Intraregionális terjeszkedésen a közeli és ismert országok felé történő terjeszkedést értjük. Vitatható annak meghatározása, hogy mely vállalat számára milyen országok tartoznak ebbe a körbe. Egy francia kiskereskedő számára például egy volt gyarmati ország felé történő terjeszkedés (például a francia alapítású Carrefour nemzetközi áruházlánc számára Algéria) beletartozik-e ebbe a körbe, vagy sem? Oh és szerzötársai [2015] kontinentális alapon végezték a csoportosítást, viszont ez nem mindig pontos. Éppen ezért mi nem bontottuk meg a terjeszkedést intra- és interregionális részre.

\footnotetext{
${ }^{1}$ https://www2.deloitte.com/global/en/pages/consumer-business/articles/global-powers-ofretailing.html.

${ }^{2} \mathrm{Az}$ éves forgalom minimum 50 százaléka élelmiszer-kiskereskedelemből származik.
} 
A vállalatok innovációs tevékenységéről a cégek honlapjairól, éves jelentésekből, üzleti hírekből (tehát másodlagos adatforrásokból) gyüjtöttünk információkat. A vállalati honlapokon a vizsgált időszakban megjelent minden új közleményt átnéztünk, az éves jelentések és az üzleti hírek esetében pedig a kiskereskedelmi innovációra jellemző keresőszavakat alkalmaztunk (például „új”, „bevezetés”). Az egyes konkrét innovációs kimeneteket az OECD-Eurostat [2005] által létrehozott tipológia szerint csoportosítottuk, majd a négy innovációtípust (termék-, marketing-, folyamat- és szervezeti innováció) vakváltozók segítségével kódoltuk (vállalatonként és évenként). Ha az adott innovációtípust jelölő vakváltozó az adott cégre az adott évben 1 értéket vett fel, az azt jelentette, hogy az adott kiskereskedő az adott évben valósította meg az adott típusú innovációt. Amennyiben nem történt ilyen innováció, a vakváltozó 0 értéket kapott. Ez a módszertani megközelítés nagyon hasonlít az Eurostat által a Community Innovation Survey (CIS) során használt méréshez.

A Global Powers of Retailing éves jelentései alapján a vállalatok konszolidált nyereségét és nettó profitrátáját használtuk teljesítménymutatókként. Mivel a vizsgált összefüggéseket számos egyéb változó is befolyásolja, kontrollváltozóként alkalmaztuk a vállalat méretét (éves árbevétel logaritmusa), a vállalat megelőző ötéves átlagos növekedési ütemét, a kiskereskedő anyaországában a háztartások végső fogyasztási kiadásainak logaritmusát, illetve ennek a növekedési ütemét. Emellett a nem megfigyelt makroökonómiai hatásokra az egyes évek vakváltozóival kontrolláltunk.

Az ökonometriai modell becslésénél kihasználtuk az adatok panelstruktúráját a potenciálisan fellépő endogenitás kezelésére. A három hipotézist különböző modellekkel teszteltük, de végig a fixhatás-modellkeretben maradtunk, hogy a vállalatokra jellemző, időben változatlan hatásokat megfelelően ki tudjuk szürni.

A $H_{1}$ hipotézis teszteléséhez diszkrét adatmodellre volt szükség. Frenz-IettoGillies [2007] többek között probit modellt alkalmazott az Eurostat Community Innovation Survey adatbázis harmadik hullámának elemzésére. Fixhatás-modellkeretben ugyanakkor a logit modell alkalmas konzisztens becslésre a NeymannScott-elv alapján (Hsiao [2014]). Más kutatók (például Chen és szerzőtársai [2014], Selim [2016]) diszkrét függő változós panelmodell alkalmazásakor szintén a logit modell mellett döntöttek, hasonló elgondolások miatt. A becsült modell a következő volt marketinginnovációk esetében:

$\operatorname{Pr}\left(\right.$ Marketing $_{i t}=1 \mid$ Országok, $\left.X_{i t} D_{t}, c_{i}\right)=$

$G\left(\beta_{1}\right.$ Országok $_{i t}+\beta_{2}$ Országok $\left._{i t}^{2}+\Gamma X_{i t}+D_{t}+c_{i}\right)$,

ahol Marketing a marketinginnovációt jelölő kétértékű változó, Országok azon országok száma, amelyekben az adott kiskereskedö az adott évben jelen volt, $X$ a vállalati és makroökonómiai kontrollváltozókat tartalmazza, $D$ az év vakváltozókat jelöli, $G(\cdot)$ pedig a logisztikus eloszlásfüggvény.

Mivel négy különböző típusú innovációt vizsgáltunk, így ebben az esetben négy modellt alkottunk. Termék-, folyamat- és szervezeti innováció esetében az (1) egyenlettel megegyező modelleket becsültünk, csak a függő változó a termék-, folyamat- és szervezeti innovációkat jelölő vakváltozók voltak. [Îgy a modellek függő változója a 
$\operatorname{Pr}\left(\right.$ Termé $\left._{i t}=1\right)$, a $\operatorname{Pr}\left(\right.$ Folyamat $\left._{i t}=1\right)$ és a $\operatorname{Pr}\left(\right.$ Szervezeti $\left._{i t}=1\right)$ voltak.] Várakozásaink szerint a $\beta_{1}$ paraméter elójele pozitív, míg a $\beta_{2}$ paraméter előjele negatív lesz, tehát a nemzetközi diverzifikáció csökkenő mértékben növeli a különféle innovációk megvalósításának valószínüségét.

A $H_{2}$ és $H_{3}$ hipotéziseket hagyományos fixhatás-modellekkel vizsgáltuk. Sohl [2012] szintén fixhatás-panelmodelleket alkalmazott a kiskereskedelmi diverzifikáció vizsgálatára. Oh és szerzőtársai [2015] dinamikus GMM-panelbecslést alkalmaztak, azonban azzal konzisztens eredményeket kaptak fixhatás-modell alkalmazása esetében is. Mindkét modellben a függő változó a kiskereskedelmi vállalatok nettó árrése volt (NetProfit), amelyet az adózás utáni eredmény és az árbevétel hányadosaként kaptunk meg.

A $H_{2}$ hipotézis teszteléséhez használt modell:

NetProfit $_{i t}=\beta_{1}$ Országok $_{i t}+\beta_{2}$ Országok $_{i t}^{2}+\beta_{3}$ Országok $_{i t}^{3}+\Gamma X_{i t}+D_{t}+c_{i}+u_{i t}$.

Végezetül, a $H_{3}$ hipotézis vizsgálata során a (3) modellt becsültük meg:

NetProfit $_{i t}=\beta_{1}$ Termék $_{i t-1}+\beta_{2}$ Marketing $_{i t-1}+\beta_{3}$ Folyamat $_{i t-1}+\beta_{4}$ Szervezeti $_{i t-1}+$ $+\gamma_{1}$ Termék $_{i t-2}+\gamma_{2}$ Marketing $_{i t-2}+\gamma_{3}$ Folyamat $_{i t-2}+\gamma_{4}$ Szervezeti $_{i t-2}+$ $+\Gamma X_{i t}+D_{t}+c_{i}+u_{i t}$

ahol Termék, Marketing, Folyamat és Szervezeti a termék-, marketing-, folyamat- és szervezeti innovációkat jelölő vakváltozók (pontosan ugyanazok, amelyeket a $H_{1}$ hipotézis tesztelésénél az egyenletek bal oldalán használtunk). Modellünkben maximum kétéves késleltetést engedtünk meg az innováció profithatásának megjelenésére.

\section{Eredmények}

Adatbázisunk a legnagyobb európai székhelyü, élelmiszereket és napi fogyasztási cikkeket forgalmazó kiskereskedőket tartalmazza. A kiválasztott cégek átlagosan 6,8 országban voltak jelen a vizsgált nyolc év átlagában, azonban emögött jelentös heterogenitás figyelhető meg. Egyes cégek mindössze egy országban képviseltették magukat, míg mások akár 52 országban is. A vállalatok terjeszkedését vizsgálva megállapítható, hogy az átlagos országszám évről évre növekedett, ugyanakkor a szórás is emelkedett, tehát nem univerzális folyamatról beszélhetünk. A vállalatok körülbelül 20 százaléka terjeszkedett intenzíven (átlagosan évente három új országba léptek be), míg a többi cég esetében érdemi országok közötti terjeszkedés nem volt megfigyelhető 2008 és 2013 között.

Az átlagos profitráta 2,3 százalék volt (a 2008 és 2013 közötti időszakban), azonban az egyes cégek és évek között jelentős eltérések tapasztalhatók. A vizsgált periódusban 2008 volt a leggyengébb év az iparágban, míg 2012 volt a legsikeresebb profit szempontjából.

Az innovációk tekintetében a termékinnovációk bizonyultak a legnépszerübbeknek, átlagosan körülbelül minden második évben valósított meg egy kiskereskedő valamilyen termékinnovációt (57 százalékos relatív gyakoriság). Ebbe a csoportba 
leginkább új vagy megújított kiskereskedelmi márkák bevezetése tartozott. Ugyanakkor más újitások is fellelhetők voltak, mint például személyre szabott termékek és szolgáltatások, bio-, gluténmentes, laktózmentes, vegetáriánus saját márkás termékek létrehozása, új csomagolások, biológiailag lebontható csomagolások kifejlesztése, kimondottan gyermekeknek szánt termékek bevezetése.

A marketinginnovációk valamivel kevésbé népszerüek, de itt is 41 százalék a relatív gyakoriság. Ebbe a körbe nagyon sokféle innováció került, az újratölthető ajándékkártyától kezdve a tematikus magazinok kibocsátásán át a legkülönbözőbb mobilapplikációkig. Több vállalat (például Sainsbury, Rewe, Migros) vezetett be új fenntarthatósági kezdeményezéseket (például olyan mobilalkalmazást, amely figyelmezteti a vásárlót, hogy hozzon magával bevásárlótáskát; koherens élelmiszer-jelölést), amelyeket szintén ebbe az innovációtípusba klasszifikáltunk. Idetartozott még például új lojalitásprogramok és társmárkázott (co-branded) bankkártyák bevezetése vagy elektromos autókhoz töltőállomások létrehozása a boltok előtt.

Folyamatinnovációk a panelben szereplő cégek esetében 36 százalékos relatív gyakorisággal fordultak elő. Itt föleg az új technológiák bevezetése volt jellemző, mint például önkiszolgáló kasszák létrehozása, elektronikus számlázási rendszer kiépítése, digitális árjelző táblák bevezetése. Ugyanakkor nagy hangsúlyt fektettek a saját disztribúciós rendszer kialakítására, az infotechnológián alapuló logisztikai fejlesztésekre és a környezetvédelemre is (például fenntartható szállítási módok, energiatakarékos rendszerek bevezetése, zöldépületek).

A szervezeti innováció volt a legkevésbé jellemző a mintában (17 százalékos relatív gyakoriság). Idetartozott például az alkalmazottak képzése (különböző tréningek és workshopok szervezése), a menedzserek kommunikációjának elősegítése az alkalmazottakkal, új rendszerek bevezetése (például SAP). Ennél az innovációtípusnál a legerősebb a megfigyelési torzítás, hiszen a szervezeti innovációk megfigyelése másodlagos adatok alapján problematikus. Ezen innovációk gyakran a háttérben zajlanak, és kevesebb információ lelhető fel róluk publikus forrásokból.

A panelmodellek eredményeit az 1. táblázatban foglaltuk össze.

Az eredmények alapján a $H_{1}$ hipotézis részben elfogadható. A nemzetközi diverzifikáció fordított $U$ alakú hatással van a folyamatinnovációra, azonban a másik három típus esetében nem találtunk szignifikáns összefüggéseket. Egy folyamatinnováció megvalósításának valószínűsége 14 ország esetében éri el a maximumot, utána viszszafordul és csökkenni kezd.

A kapott eredmények arra utalnak, hogy a marketing- és termékinnovációk esetében kisebb a több országban való jelenlét okozta szinergia, tehát jellemzően országspecifikus innovációkról beszélhetünk. A folyamatinnovációk viszont éppen akkor kerülnek elötérbe, amikor több országban van már jelen az adott vállalat, így az innovációból származó előny nagyobb, illetve a folyamatok standardizálása és megújítása iránti igény is növekszik. A fordított $U$ alakú hatás mögött az húzódhat meg, hogy nagyon sok országnál a koordináció annyira bonyolulttá válik, hogy az ilyen sok országot átfogó folyamatinnovációk igen ritkák már.

A $H_{2}$ hipotézist (nemzetközi diverzifikáció hatása a teljesítményre) illetően az $S$ alakú kapcsolat létét nagy biztonsággal el tudjuk utasítani, míg - a fordított $U$ alakú 
1. táblázat

Panelbecslések eredményei (standardizálatlan regressziós koefficiensek)

\begin{tabular}{|c|c|c|c|c|c|c|}
\hline \multirow[b]{2}{*}{ Változók } & \multicolumn{4}{|c|}{$H_{1}$} & \multirow{2}{*}{$\begin{array}{c}\mathrm{H}_{2} \\
\text { nettó } \\
\text { profitráta }\end{array}$} & \multirow{2}{*}{$\begin{array}{c}H_{3} \\
\text { nettó } \\
\text { profitráta }\end{array}$} \\
\hline & termék & marketing & szervezeti & folyamat & & \\
\hline Országok & 0,1404 & $-0,1781$ & $-0,3741$ & $0,4381^{\star *}$ & $0,0045^{\star *}$ & \\
\hline Országok² & $-0,0017$ & 0,0051 & 0,0337 & $-0,0158^{\star *}$ & $-0,0001^{\star}$ & \\
\hline Országok ${ }^{3}$ & & & & & $1,08 \mathrm{e}-06$ & \\
\hline Termék $_{t-1}$ & & & & & & $0,0144^{\star}$ \\
\hline Marketing $_{t-1}$ & & & & & & $0,0250^{\star * *}$ \\
\hline Szervezeti $_{t-1}$ & & & & & & $-0,0009$ \\
\hline Folyamat $_{t-1}$ & & & & & & 0,0107 \\
\hline Termék $_{t-2}$ & & & & & & 0,0095 \\
\hline Marketing $_{t-2}$ & & & & & & 0,0118 \\
\hline Szervezeti $_{t-2}$ & & & & & & $-0,0008$ \\
\hline Folyamat $_{t-2}$ & & & & & & $0,0149^{\star}$ \\
\hline $\begin{array}{l}\text { Megfigyelések } \\
\text { száma }\end{array}$ & 188 & 176 & 111 & 185 & 173 & 104 \\
\hline Cégek száma & 32 & 30 & 19 & 31 & 31 & 30 \\
\hline Pszeudo $R^{2}$ & 0,11 & 0,09 & 0,21 & 0,09 & - & - \\
\hline Belső $R^{2}$ & - & - & - & - & 0,13 & 0,32 \\
\hline
\end{tabular}

Megjegyzés: minden regresszió tartalmazott év vakváltozókat, időben változó vállalatspecifikus (log árbevétel, árbevétel elmúlt ötéves növekedése) és makroökonómiai kontrollváltozókat (háztartások végső fogyasztási kiadásai a kereskedő anyaországában, a háztartások végső fogyasztási kiadásainak növekedése a kereskedő anyaországában).

${ }^{* * *} 1$ százalékos, ${ }^{\star *} 5$ százalékos, ${ }^{\star} 10$ százalékos szinten szignifikáns.

és a teljesen lineáris kapcsolat közül - a fordított $U$ alakú kapcsolat fogadható el 10 százalékos szignifikanciaszinten. Ugyanakkor a fordulópont 23 országnál van, és mindössze az esetek 7 százalékában volt 23-nál több országban jelen egy adott kiskereskedő. Az eredmények azt mutatják, hogy a kevés országba való terjeszkedés jövedelmező. A mindössze néhány országban jelen lévő vállalatok (például Migros, Système U, X5 Retail, El Corte Inglés) vagy a környező országok, vagy a volt gyarmatok felé terjeszkedtek, tehát az ismert piacokat részesítették előnyben. Az ennél több országban jelen lévő vállalatok esetében fordult elö tengerentúli vagy ázsiai terjeszkedés, ahol a kevésbé ismert, nagyon eltérő piacokra léptek ki a vállalatok. Az a tény, hogy a négyzetes tag csak 10 százalékos szinten szignifikáns, arra utal, hogy néhány vállalat hatékonyan alkalmazkodott a távolabbi piacokhoz, míg mások számára az adaptációs költségek csökkentették, akár teljesen fel is emésztették a terjeszkedésből származó hasznot. Ezek az eredmények összhangban vannak Qian és szerzötársai [2010] elméletével. 
A $H_{3}$ hipotézis esetében a profitabilitás és a marketinginnováció között szignifikáns kapcsolatot találtunk. Ha egy adott kiskereskedő egy adott évben megvalósított valamilyen marketinginnovációt, akkor várhatóan a következő évben 2,5 százalékponttal nagyobb profitrátára számíthatott, amely erösen közelít a vizsgált vállalatok átlagos profitrátájához. Ez a marketinginnovációk igen jelentős megtérülésére utal. Termékinnovációk esetében a hatás kisebb és kevésbé szignifikáns. Egy termékinnováció (például új kiskereskedelmi márkás termékvonal bevezetése) várhatóan 1,4 százalékponttal növeli meg a kereskedőcég profitrátáját az innováció bevezetését követő évben.

Folyamatinnovációk esetében csak a második évben látható érdemi hatás, ami arra utal, hogy ezen innovációknak több idő kell, hogy beérjenek. Szervezeti innováció esetében nem találtunk érdemi összefüggéseket, amiben a már említett, jelentősebb megfigyelési torzítás is szerepet játszhat.

Eredményeink alapján a különböző innovációtípusoknak eltérő profithatásaik vannak. Emögött több tényező is meghúzódhat.

Míg a marketing- és termékinnovációk azonnal láthatók a fogyasztók számára, így hatásuk gyorsan megjelenik, addig a folyamatok fejlesztése, átalakítása hosszabb időt vesz igénybe, és a belöle várható megtakarítás vagy bevételnövekedés is lassabban materializálódik.

A termékinnovációk könnyebben másolhatók a versenytársak számára, hiszen egy-egy új kiskereskedelmi márkás termékvonal bevezetése a beszállítók kiválasztása után gyorsan megtörténhet. Ráadásul ennél az innovációtípusnál a költségek nagyobb része jelentkezik a beszállítóknál (például termékfejlesztés, új gyártósor beszerzése), ezzel tovább könnyítve a termékinnovációk megvalósítását a kereskedők számára. Ezzel szemben a marketinginnovációk sokkal egyedibbek, például egy hüségkártyarendszer vagy mobilalkalmazás fejlesztéséhez több idő és nagyobb tőke szükséges. A nehezebb utánozhatóság és a magasabb költségek okai lehetnek a magasabb várható megtérülésnek is.

\section{Következtetések és összegzés}

Kutatásunk során azt vizsgáltuk, hogy miként hat a nemzetközi diverzifikáció a nagy európai élelmiszer-kiskereskedelmi vállalatok piaci teljesítményére és innovációs tevékenységére, illetve a különböző innovációk milyen mértékben befolyásolják a vállalatok profitabilitását.

A földrajzi diverzifikáció és a profitabilitás között fordított $U$ alakú kapcsolatot találtunk, ami arra utal, hogy az országok közötti terjeszkedésnek van egy optimuma (23 ország), amely fölött a jelentkező költségek növekedése nagyobb, mint a diverzifikációból származó inkrementális haszon. A két változó közötti nem lineáris kapcsolat összhangban van korábbi kutatási eredményekkel (Hitt és szerzőtársai [2006], Sohl [2012], Oh és szerzötársai [2015]), ugyanakkor a kapcsolat pontos alakjára (fordított $U$ vagy $S$ alakú) vonatkozóan eltérö eredmények születtek. Ebben szerepet játszhat az is, hogy Oh és szerzőtársaival [2015] ellentétben nem bontottuk meg a földrajzi diverzifikációt 
intra- és interregionális részre. Ennek oka, hogy az európai kiskereskedők elöszeretettel terjeszkedtek volt gyarmati országok felé, amelyek Európán kívüliek, de mégis közel állnak az anyaországhoz történelmi kapcsolataik révén.

Eredményeink alapján a különböző innovációtípusokat érdemes különválasztani. A marketinginnovációk megvalósítására a földrajzi kiterjedtség nem hat szignifikánsan, ami vélhetően a különféle országok eltérő szokásaival és kultúrájával magyarázható. Az a reklámkampány, hüségprogram vagy mobilalkalmazás, amely sikeres az egyik országban, nem biztos, hogy máshol is az. Éppen ezért az országok közötti szinergia korlátozott. Másfelől viszont a marketinginnovációknak kiemelkedően kedvező profithatásuk van már egy évvel a bevezetésük után is; a kereskedők nettó profitrátáját várhatóan 2,5 százalékponttal emelik meg. Ez összefügghet a marketinginnovációk nehezebb és lassabb másolhatóságával.

Termékinnovációk esetében (amelyek legtöbbször kiskereskedelmi márkás termékek fejlesztését jelentik) sem találtunk kapcsolatot a földrajzi diverzifikáció és az innováció megvalósítási valószínűsége között. Ugyanakkor a termékinnovációk pénzügyi hatása is igen kedvező, az innovációt követő évben várhatóan 1,4 százalékponttal lesz magasabb a kiskereskedő nettó profitrátája. E hatás értékelésekor figyelembe kell venni, hogy vizsgálatunk során 2008 és 2013 közötti adatokat elemeztünk. A válság alatt és után a kiskereskedelmi márkák iránti kereslet jelentősen megnőtt, illetve a kínálat is kibővült. A kiskereskedelmi márkákon általában magasabb árrést és nyereséget érnek el a kereskedők, mint a gyártói márkás termékeken (Dunne-Lusch [2008]), tehát e piaci folyamat kedvezett a kereskedőknek.

Egyedül a folyamatinnovációkra hat pozitívan a földrajzi terjeszkedés, a hatás csúcspontját 14 országnál éri el. Egy több, föként egymáshoz közeli országokban jelen lévő vállalat különféle folyamatfejlesztésekkel aknázhatja ki az országok közelségéből fakadó szinergiát. Ennek következménye lehet a folyamatinnovációk pozitív profithatása is, amely ugyanakkor csak két évvel az innováció megvalósításának kezdete után jelentkezik. Eredményeink azt támasztják alá, hogy a logisztikai, szállítmányozási és disztribúciós területeket érintő innovációk kedvezö befektetési lehetőségek lehetnek.

Végezetül, a szervezeti innovációk esetében semmilyen szignifikáns hatást sem sikerült kimutatnunk. Ennek oka lehet egyrészt, hogy ezen innovációknak (például tudásmenedzsment, külső érdekeltekkel való kapcsolattartás, belső tréningrendszerek) nincs annyira közvetlen hatásuk a vállalat eredményességére, mint például egy marketing- vagy termékinnovációnak. Másrészt, a szervezeti innovációk másodlagos adatokból történő megfigyelése a leginkább problematikus. Ennél az innovációtípusnál a legnagyobb a megfigyelésekből adódó torzítás.

Eredményeink tudományos és üzleti hasznosítására több lehetőség is kínálkozik. Tudományos szempontból a kiskereskedelmi innovációk vizsgálata, illetve a földrajzi terjeszkedéssel és a pénzügyi eredményességgel való összefüggéseik elemzése kevéssé kutatott területnek számít. Meglátásunk szerint ennek oka, hogy a kiskereskedelmi innovációk legtöbb esetben vertikális együttmüködésen alapulnak, emiatt nehéz megfelelő adatokat találni az innováció mérésére. Továbbá, a kiskereskedők szempontjából hasznos a különféle innovációk megtérülésének ismerete, illetve ezek kapcsolata a 
földrajzi diverzifikációval. Ez segíthet a kiskereskedők jövőbeli stratégiájának megalkotásában és a különbözö (például terjeszkedési és innovációs) célok összehangolásában. Eredményeink alapján az látszik, hogy a marketing- és termékinnovációk megvalósításáról nemzeti szinten érdemes dönteni, míg a folyamatinnovációk esetében ki kell használni a nemzetközi piacon kialakuló szinergikus hatásokat. Tekintve, hogy eredményeink alapján a marketinginnovációk megvalósítása a leginkább kifizetődő, egy olyan kiskereskedőnek, aki csak néhány ország piacán van jelen, leginkább erre az innovációtípusra érdemes figyelnie. Egy nagyobb, sok országban megjelenő kiskereskedő esetében pedig érdemes folyamatinnovációkon is gondolkodni.

A kutatás korlátai elsősorban a másodlagos adatok felhasználásához és az innováció méréséhez kapcsolódnak. A szekunder adatmegfigyelés során nem lehetséges a célsokaság teljes megfigyelése. A megfigyelési torzítás minden innovációtípus esetében megjelenik, ez ugyanakkor leginkább a szervezeti innovációk esetében problematikus. Az innovációs tevékenység vakváltozókkal való mérése további fejlesztésre szorul, hogy még részletesebb és robusztusabb eredményeket kaphassunk. Többféle irány mutatkozik a kutatás folytatására. Egyrészt, érdemes lehet összevetni az élelmiszer-kiskereskedöket más árucsoportokra szakosodott kiskereskedőkkel. Másrészt, érdekes lehet egy-egy innovációs típust részletesebben is megvizsgálni, a megjelenő mintázatokat elemezni.

\section{Hivatkozások}

Bauer, A.-CARman, J. M. [1996]: Toward Explaining Differences in the Transition of the Distribution Sector of Central European Economies. Megjelent: Bultez, A.-Parsons, L. (szerk.): Channel Productivity: Efficiency in Retailing and Merchandising. Mons, Belgium.

Brondoni, S. M.-Corniani, M.-Riboldazzi, S. [2013]: Global retailers, market-driven management and innovation. The International Journal of Economic Behavior, Vol. 3. No. 1. 27-40. o.

Burt, S.-Davies, K.-Dawson, J.-Sparks, L. [2008]: Categorizing patterns and processes in retail grocery internationalization. Journal of Retailing and Consumer Services, Vol. 15. No. 2. 78-92. o. http://dx.doi.org/10.1016/j.jretconser.2007.05.008.

CAscio, R. P. [2011]: Marketing innovation and firm performance research model, research hypotheses, and managerial implications. PhD-dolgozat, University of Central Florida, Orlando, Florida.

Castellani, D.-Zanfei, A. [2007]: Internationalisation, innovation and productivity: How do firms differ in Italy? The World Economy, Vol. 30. No. 1. 156-176. o. https://doi. org/10.1111/j.1467-9701.2007.00875.x.

Chan, P.-Finnegan, C.-Sternquist, B. [2011]: Country and firm level factors in international retail expansion. European Journal of Marketing, Vol. 45. No. 6. 1005-1022. o. http:// dx.doi.org/10.1108/03090561111119985.

Chen, Y. [2006]: Marketing innovation. Journal of Economics and Management Strategy, Vol. 15. No. 1. 101-123. o. https://doi.org/10.1111/j.1530-9134.2006.00093.x.

Chen, Z.-Daito, N.-Gifford, J. L. [2014]: Do State Fiscal Constraints Affect Implementation of Highway Public-Private Partnerships? A Panel Fixed Logit Assessment. Journal of the Transportation Research Forum, Vol. 53. 111-128. o. 
Damanpour, F.-Walker, R. M.-Avellaneda, C. N. [2009]: Combinative effects of innovation types and organizational performance: A longitudinal study of service organizations. Journal of Management Studies, Vol. 46. No. 4. 650-675. o. http://dx.doi.org/10.1111/j.14676486.2008.00814.x.

Dellestrand, H. [2011]: Subsidiary embeddedness as a determinant of divisional headquarters involvement in innovation transfer processes. Journal of International Management, Vol. 17. No. 3. 229-242. o. http://dx.doi.org/10.1016/j.intman.2011.05.005.

Deloitte [2009]: Global Powers of Retailing 2009. Feeling the squeeze. Deloitte, London. Deloitte [2015]: Global Powers of Retailing 2015. Embracing innovation. Deloitte, London. Deloitte [2016]: Global Powers of Retailing 2016. Navigation the new digital divide. Deloitte, London.

DREJER, I. [2004]: Identifying innovation in surveys of services: A Schumpeterian perspective. Research Policy, Vol. 33. No. 3. 551-562. o. http://dx.doi.org/10.1016/j.respol. 2003.07.004.

Dunne, P. M.-Lusch, R. F. [2008]: Retailing. 6. kiadás. South-Western Cengage Learning, Mason. Filippetti, A.-Frenz, M.-Ietto-Gillies, G. [2013]: The role of internationalization as a determinant of innovation performance. An analysis of 42 countries. CIMR Research Working Paper Series, No. 10. CIMR, London, https://doi.org/10.2139/ssrn.2114289.

ForNARI, D.-GRANDI, S.-FornARI, E. [2009]: The role and management of product innovation in retailer assortments: Evidence from the Italian FMCG market. International Review of Retail, Distribution and Consumer Research, Vol. 19. No. 1. 29-43. o. http://dx.doi. org/10.1080/09593960902781235.

FrenZ, M.-Ietto-Gillies, G. [2007]: Does Multinationality Affect the Propensity to Innovate? An Analysis of the Third UK Community Innovation Survey. International Review of Applied Economics, Vol 21. No. 1. 99-117. o. https://doi.org/10.1080/02692170601035033.

Geroski, P.-Machin, S.-Reenen, J. V. [1993]: The profitability of innovating firms. RAND Journal of Economics, Vol. 24. No. 2. 198-211. o. https://doi.org/10.2307/2555757.

Gielens, K.-Dekimpe, M. G. [2001]: Do international entry decisions of retail chains matter in the long run? International Journal of Research in Marketing, Vol. 18. No. 3. 235-259. o. ttps://doi.org/10.1016/s0167-8116(01)00039-8.

Grewal, D.-Ailawadi, K. L.-Gauri, D.-Hall, K.-Kopalle, P.-Robertson, J. R. [2011]: Innovations in retail pricing and promotions. Journal of Retailing, Vol. 87. No. S1. S43-S52. o. http://dx.doi.org/10.1016/j.jretai.2011.04.008.

Hassan, M. U.-Shaukat, S.-Nawaz, M. S.-Naz, S. [2013]: Effects of innovation types on firm performance: An empirical study on Pakistan's manufacturing sector. Pakistan Journal of Commerce and Social Sciences, Vol. 7 No. 2. 243-262. o.

Hitt, M.-Hoskisson, R. E.-Ireland, R. D. [1994]: A Mid-range theory of the interactive effects of international and product diversification on innovation and performance. Journal of Management, Vol. 20. No. 2. 297-326. o. https://doi.org/10.1177/014920639402000203.

HitT, M.-Hoskisson, R. E.-Kim, H. [1997]: International Diversification: Effects on Innovation and Firm Performance in Product-Diversified Firms. Academy of Management Journal, Vol. 40. No. 4. 767-798. o. http://dx.doi.org/10.2307/256948.

Hitt, M.-Tihanyi, L.-Miller, T.-Connelly, B. [2006]: International Diversification: Antecedents, Outcomes, and Moderators. Journal of Management, Vol. 32. No. 6. 831-867. o. https://doi.org/10.1177/0149206306293575.

HRISTOV, L.-REYNOLDS, J. [2007]: Innovation in the UK retail sector. Report for NESTA December 2007. The Oxford Institute of Retail Management, Said Business School, Oxford. 
Hristov, L.-Reynolds, J. [2015]: Perceptions and practices of innovation in retailing. International Journal of Retail and Distribution Management, Vol. 43. No. 2. 126-147. o. http://dx.doi.org/10.1108/IJRDM-09-2012-0079.

HsiaO, C. [2014]: Analysis of Panel Data. 3. kiadás, Cambridge University Press, New York, https://doi.org/10.1017/cbo9781139839327.

INAUEN, M.-SCHENKER-WiCKI, A. [2012]: Fostering radical innovations with open innovation. European Journal of Innovation Management, Vol. 15. No. 2. 212-231. o. http://dx.doi. org/10.1108/14601061211220986.

LEVITT, T. [1960]: Growth and profits through planned marketing innovation. Journal of Marketing, Vol. 24. No. 4. 1-8. o. https://doi.org/10.2307/1248397.

Medina, C.-Rufín, R. [2009]: The mediating effect of innovation in the relationship between retailers' strategic orientations and performance. International Journal of Retail and Distribution Management, Vol. 37. No. 7. 629-655. o. http://dx.doi.org/10:1108/ 09590550910964639.

Michalache, M. [2015]: Leveraging the International Context. Essays on building offshoring capabilities and enhancing firm innovation. Doctoral Thesis. Erasmus Research Institute of Management, Rotterdam.

Neely, A.-Fillippini, R.-Forza, C.-Vinelli, A.-HiI, J. [2001]: A framework for analysing business performance, firm innovation and related contextual factors: Perception of managers and policy makers in two European regions. Integrated Manufacturing Systems, Vol. 12. No. 2. 114-124. o. http://dx.doi.org/10.1108/09576060110384307.

Niemeier, S.-Zocchi, A.-Catena, M. [2013]: Reshaping retail: Why technology is transforming the industry and how to win in the new consumer driven world. John Wiley and Sons, Chichester.

OECD-Eurostat [2005]: Oslo Manual. Guidelines for Collecting and Interpreting Innovation Data. 3. kiadás, OECD-Eurostat, Párizs, http://dx.doi.org/10.1787/9789264013100-en.

$\mathrm{OH}$, C. H.-Sohl, T.-Rugman, A. M. [2015]: Regional and product diversification and the performance of retail multinationals. Journal of International Management, Vol. 21. No. 3. 220-234. o. http://dx.doi.org/10.1016/j.intman.2015.04.002.

Pantano, E. [2014]: Innovation management in retailing: From consumer perspective to corporate strategy. Journal of Retailing and Consumer Services, Vol. 21. No. 5. 825-826. o. http://dx.doi.org/10.1016/j.jretconser.2014.02.017.

Pantano, E.-Viassone, M. [2014]: Demand pull and technology push perspective in technologybased innovations for the points of sale: The retailers evaluation. Journal of Retailing and Consumer Services, Vol. 21. No. 1.43-47. o. http://dx.doi.org/10.1016/j.jretconser.2013.06.007.

Pederzoli, D.-Kuppelwieser, V. G. [2015]: Retail companies' internationalization behavior and the 2008 crisis. International Journal of Retail and Distribution Management, Vol. 43. No. 9. 870-894. o. http://dx.doi.org/10.1108/IJRDM-07-2014-0109.

Qian, G.-Khoury, T. A.-Peng, M. W.-Qian, Z. [2010]: The performance implications of intra- and inter-regional geographic diversification. Strategic Management Journal, Vol. 31. No. 9. 1018-1030. o. https://doi.org/10.1002/smj.855.

Reinartz, W.-Dellaert, B.-Kraft, M.-Kumar, V.-Varadarajan, R. [2011]: Retailing innovations in a globalizing retail market environment. Journal of Retailing, Vol. 87. No. S1. S53-S66. o. http://dx.doi.org/10.1016/j.jretai.2011.04.009.

Reynolds, J.-Howard, E.-Cuthbertson, C.-Hristov, L. [2007]: Perspectives on retail format innovation: Relating theory and practice. International Journal of Retail and Distribution Management, Vol. 35. No. 8. 647-660. o. http://dx.doi.org/10.1108/09590550710758630. 
Rugman, A. M.-OH, C. H.-Lim, D. S. K. [2012]: The regional and global competitiveness of multinational firms. Journal of Academy of Marketing Science, Vol. 40. No. 2. 218-235. o. http://dx.doi.org/10.1007/s11747-011-0270-5.

Salmon, W. J.-Tordjman, A. [1989/2009]: The Internationalisation of Retailing. Megjelent: Coe, N. M.-Wrigley, N. (szerk.): The Globalization of Retailing. The Globalization of the World Economy series. Edward Elgar, 1. kötet, 8-21. o.

SCHUMPETER, J. A. [1911/1980]: A gazdasági fejlődés elmélete. Vizsgálódás a vállalkozói profitról, a tőkéről, a hitelről, a kamatról és a konjunktúraciklusokról. Közgazdasági és Jogi Könyvkiadó, Budapest.

SELIM, S. [2016]: Socio-economic Determinants of Poverty in Turkey: Panel Logit Approach. International Journal of Statistics and Economics, Vol. 17. No. 3. 71-84. o.

Shankar, V.-Inman, J. J.-Mantrala, M.-Kelley, E.-Rizley, R. [2011]: Innovations in shopper marketing: Current insights and future research issues. Journal of Retailing, Vol. 87. No. S1. S29-S42. o. http://dx.doi.org/10.1016/j.jretai.2011.04.007.

SiedsChlaG, I.-ZhANG, X. [2015]: Internationalisation of firms and their innovation and productivity. Economics of Innovation and New Technology, Vol. 24. No. 3-4. 183-203. o. https://doi.org/10.1080/10438599.2014.918439.

SoHL, T. [2012]: Diversification strategies in the global retailing industry: Essays on the dimensions and performance implications. Doctoral Dissertation: University of St. Gallen, School of Management, Economics, Law, Social Sciences and International Affairs, Sankt-Gallen.

Treadgold, A. [1988/2009]: Retailing without frontiers: The emergence of transnational retailers. Megjelent: Coe, N. M.-Wrigley, N. (szerk.): The Globalization of Retailing. The Globalization of the World Economy series. Edward Elgar, 1. kötet, 3-7. o.

Wiersema, M. F.-Bowen, H. P [2011]: The relationship between international diversification and firm performance: Why it remains a puzzle. Global Strategy Journal, Vol. 1. No. 1. 152-170.o. http://dx.doi.org/10.1002/gsj.5.

XIE, Z.-LI, J. [2015]: Demand Heterogeneity, Learning Diversity and Innovation in an Emerging Economy. Journal of International Management, Vol. 21. No. 4. 277-292. o. http:// dx.doi.org/10.1016/j.intman.2014.12.003.

Zahra, S. A.-Ireland, R. D.-Hitt, M. A. [2000]: International Expansion by New Venture Firms: International Diversity, Mode of Market Entry, Technological Learning, and Performance. Academy of Management Journal, Vol. 43. No. 5. 925-950. o. http://dx.doi. org/10.2307/1556420. 